$2010-10$

\title{
A review of bast fibres and their composites. Part 1 - Fibres as reinforcements
}

\author{
Summerscales, John
}

http://hdl.handle.net/10026.1/9928

\subsection{6/j.compositesa.2010.06.001 \\ Composites Part A: Applied Science and Manufacturing ELSEVIER SCI LTD}

All content in PEARL is protected by copyright law. Author manuscripts are made available in accordance with publisher policies. Please cite only the published version using the details provided on the item record or document. In the absence of an open licence (e.g. Creative Commons), permissions for further reuse of content should be sought from the publisher or author. 


\section{A Review of Bast Fibres and their Composites. Part 1 - fibres as reinforcements John Summerscales ${ }^{\mathrm{a}, \mathrm{c}}$, Nilmini PJ Dissanayake ${ }^{\mathrm{a}}$, Amandeep S Virk ${ }^{\mathrm{a}}$ and Wayne Hall ${ }^{\mathrm{b}}$}

(a) Advanced Composites Manufacturing Centre, School of Marine Science and Engineering Reynolds Building, University of Plymouth, Plymouth, Devon PL4 8AA, United Kingdom.

(b) Griffith School of Engineering, Gold Coast campus, Griffith University, Queensland 4222, Australia

(c) corresponding author. E-mail: jsummerscales@plymouth.ac.uk

\section{Abstract:}

Bast fibres are defined as those obtained from the outer cell layers of the stems of various plants. The fibres find use in textile applications and are increasingly being considered as reinforcements for polymer matrix composites as they are perceived to be "sustainable". The fibres are composed primarily of cellulose which potentially has a Young's modulus of $\sim 140 \mathrm{GPa}$ (being a value comparable with man-made aramid [Kevlar/Twaron] fibres). The plants which are currently attracting most interest are flax and hemp (in temperate climates) or jute and kenaf (in tropical climates). This review paper will consider the growth, harvesting and fibre separation techniques suitable to yield fibre of appropriate quality. The text will then address characterisation of the fibre as, unlike man-made fibres, the cross section is neither circular nor uniform along the length.

\section{Introduction}

Chand et al, [1], Lilholt and Lawther [2], and Franck [3] have reviewed the technology of natural fibres. Bolton [4], Mohanty and Misra [5], Nabi Saheb and Jog [6], Bledzki et al [7], Netravali [8], Baillie [9], Mohanty et al [10] and Pickering [11] have reviewed the use of natural fibres in polymer composites. The intention of this paper is to review the use of bast (plant stem) fibres in the context of fibre-reinforced polymer-matrix composites. This paper will not address natural fibres from animals (eg silk [12] or wool [13]) or those resulting from wood, seeds ( $e g$ coir or cotton), leaves (eg abaca, pineapple [14] or sisal [15]) or grasses (bamboo, miscanthus or wheat) which have at various times been considered as reinforcements for composites. Given the broad scope of this article, it will inevitably be incomplete, but will hopefully provide a sensible overview of the topic.

The majority of plant fibres which are being considered as reinforcements for polymeric materials are bast fibres, defined as fibres obtained from the outer cell layers of the stems of various plants [16]. All the important natural fibres were in textile use thousands of years ago with flax used in Egypt at least 7000 years ago. Archaeologists have found evidence that even Stone Age man knew how to twist short lengths of fibre together to form cords and yarns, using a spinning process not very different from that used in primitive parts of the world to this day [17]. Kvavadze et al [18] have recently reported finding twisted wild flax fibres indicating that prehistoric hunter-gatherers were making cords for hafting stone tools, weaving baskets, or sewing garments around Dzudzuana Cave (Georgia) up to 30 thousand years before the present.

\section{Temperate regions}

Flax: Linum usitatissimum [19-23] grown for fibre and linseed grown for seed oil are cultivars (varieties of the same plant species bred with an emphasis on the required product). In the UK the flax plant is normally sown in March-May and may grow to one-metre high dependent on the variety (there are 180 species [21]). The Flax Crop Production page of the Flax Council of Canada (FCC) website [23] is an especially useful resource giving comprehensive details of the husbandry of this plant. The life cycle of the flax plant has 12 distinct growth stages [19]. In 1941, flax and hemp (with wheat and spruce pulp) fibres were used in resin matrix composites for the bodywork of a Henry Ford car which was claimed to have an "impact strength 10 times greater than steel" [24]. Flax is amongst the natural fibres now finding use in thermoplastic matrix composite panels for internal structures in the car industry (including car door panels, car roof and boot linings, and parcel shelves) [25, 26].

Hemp Cannabis sativa $L$ is an annual plant native to central Asia and known to have been grown in China over 4500 years ago [21]. It probably reached central Europe in the Iron Age (circa $400 \mathrm{BC}$ ) and there is evidence of growth in the UK by the Anglo-Saxons (800-1000 AD). It does not require fertiliser, herbicides or pesticides to grow well (and hence is potentially of great interest in the context of sustainability). In suitable warm conditions, it can grow to 4 metres in just 12 weeks. True hemp is a fine, light-coloured, lustrous and strong bast fibre obtained by retting (see below). The colour and cleanliness vary considerably according to the method of preparation of the fibre. The lower grades are dark cream and contain much non-fibrous matter. The main producing areas are Italy, Yugoslavia and Russia [16]. The fibre ranges in length from 1.0-2.5 $\mathrm{m}$. The term hemp is often used incorrectly in a generic sense for fibres from different plants, e.g. abaca (manila hemp), sisal (sisal hemp) and sunn fibre (sunn hemp) [16]. Hemp, is amongst the natural fibres now finding use in thermoplastic matrix composites for internal structures in similar automotive applications to those for flax fibres. 
Nettle: European nettle Urtica dioica [27-29] and Himalayan nettle Girardinia diversifolia [30]. Nettle is another plant-stem fibre which may find application as a reinforcement. The yield of nettle fibre ranges from 335 to $411 \mathrm{~kg} / \mathrm{ha}$ in the second year and from 743 to $1016 \mathrm{~kg} / \mathrm{ha}$ in the third year [31]. The fibres are far stronger than cotton but finer than other bast fibres such as hemp. They are a much more environmentally friendly fibre crop than cotton, which requires more irrigation and agrochemical input. Lewington [21] states that "during the Second World War ... Britain's Ministry of Aircraft Production experimented with the use of a very strong, high-grade paper made from nettle fibre for reinforcing plastic aircraft panels as well as gear wheels and other machine parts".

\section{Tropical regions}

Jute: Corchorus capsularis (white jute) and Corchorus olitorius (dark jute) fibre is obtained from the bast layer of the plants. Each of the above classes is further sub-divided into numerous grades denoting quality and other characteristics. Jute is the second most common natural fibre (after cotton) cultivated in the world. It is an annual plant that flourishes in monsoon climates and grows to 2.5-4.5 m [21]. It is primarily grown in Bangladesh, Brazil, China, India and Indonesia. Jute-based thermoplastic matrix composites find a substantial market in the German automotive door-panel industry (growing from 4000 tonnes in 1996 to over 21000 tonnes in 1999 and rising) [21]. Typical fibre length and cross-sectional area distributions for jute fibre are given in Figures 1 and 2 respectively.

\section{Figure 1: Fibre length distribution from 100g of jute fibres (courtesy of Richard Cullen) Figure 2: Distribution of fibre cross-sectional areas for jute fibres (Virk data)}

Kenaf: Hibiscus cannabinus, is a warm season, short-day, annual herbaceous fibre plant native to central Africa, and a common wild plant of tropical and subtropical Africa and Asia. It has been cultivated since around $4000 \mathrm{BC}$ for food and fibre. It is known as mesta in India and Bengal, as stockroot in South Africa, as java jute in Indonesia and as ambari in Taiwan. The plant has a unique combination of long bast (about $35 \%$ of the stalk dry weight) with short core fibres in place of the hollow core [16, 32]. Kenaf belongs to the Malvaceae, a family notable for both its economic and horticultural importance. Kenaf has a high growth rate, rising to heights of 4-6 $\mathrm{m}$ in about 4-5 months. Strong interest is being shown in this plant in Malaysia as it is fast growing and can yield two crops/year in the local climate. It can then yield a dry weight of 6000-10000 kg/ha.year (new varieties may reach $30000 \mathrm{~kg} / \mathrm{ha}$.year). It is similar to jute in many of its properties and may be used either as an alternative to, or in admixture with, jute.

\section{Fibre growth and processing}

The typical production cycle for flax is given below.

Tillage is the preparation of land for cropping by ploughing, harrowing or similar operations. Conventional tillage is preferred in flax cultivation which is primary tillage followed by early spring tillage and planting. No-till methods have been trialled by some growers with no significant change in flax yield [33]. Agricultural lime $\left(\mathrm{CaCO}_{3}\right)$ may be applied to maintain soil $\mathrm{pH}$. For flax grown in the UK, typical levels of fertiliser are $40 \mathrm{~kg} / \mathrm{ha}$ of nitrogen $(\mathrm{N}), 50 \mathrm{~kg} / \mathrm{ha}$ of phosphorus (P) as $\mathrm{P}_{2} \mathrm{O}_{3}$ and $50 \mathrm{~kg} / \mathrm{ha}$ of potassium $(\mathrm{K})$ as $\mathrm{K}_{2} \mathrm{O}$ [34], while for flax grown in Northern Ireland (NI), the suggested levels of fertiliser are $20 \mathrm{~kg} / \mathrm{ha} \mathrm{N}, 20 \mathrm{~kg} / \mathrm{ha} \mathrm{P}_{2} \mathrm{O}_{5}$ (equivalent to $15.5 \mathrm{~kg}$ of $\mathrm{P}_{2} \mathrm{O}_{3}$ ) and $80 \mathrm{~kg} / \mathrm{ha} \mathrm{K} 2 \mathrm{O}$ [19].

Drilling (planting) the seed usually starts at the end of February in Belgium, France and the Netherlands and ends in early April in NI. Flax is planted in narrow rows (150-200 mm apart) using similar equipment to that used for cereals. Optimum seed depth is $25-40 \mathrm{~mm}$ and optimum seeding rates are $35-50 \mathrm{~kg} / \mathrm{ha}$ [33].

Weed control: Flax is a poor competitor with weeds which can contaminate the scutched (i.e. decorticated - see below) flax fibres. Herbicides are usually applied to control the growth of undesirable species.

Plant growth for flax consists of a 45-60 day vegetative period, a 15-25 day flowering period and a maturation period of 30-40 days and is well illustrated in Turner [19].

Dessication (drying) of the crop has numerous advantages over field retting (see below) including earlier harvesting, elimination of the need for swathing (lying after being cut), reduction in combining time and less wear and tear on machinery. A glyphosate chemical treatment is typically applied 10-14 days after full flower (at about mid-July in NI). Glyphosate is only used where stand retting (see below) is adopted followed by direct combine harvesting of the crop.

Harvest is normally in August or September by either combine harvester or pulling, The latter is more labour intensive but yields fibre with less damage.

Rippling is the removal of flax seed capsules by drawing stems through a coarse steel comb.

Retting is the subjection of crop or deseeded straw to chemical or biological fermentation treatments to make the fibre bundles more easily separable from the woody part of the stem. Flax can be stand-retted (before harvest), dew-retted (cut and left in in the field), water-retted (immersed in tanks) or chemically-retted (in process tanks). Enzymes (e.g. pectinase digests the pectin binder [35]) may be used to assist the retting process. Termination of the retting process may be a problem and failure to achieve this can result in reduced fibre properties. Pre-harvest stand-retting of flax, when glyphosate is applied at the mid-point of flowering, depends on uniform desiccation of the entire stem and is difficult to achieve during a dry season [36]. Both dew-retting and stand-retting of the desiccated flax in the field rely on invasion by natural microorganisms and are dependent on the vagaries of the weather. 
Decortication $[37,38]$ is the mechanical removal of non-fibrous material from retted stalks or from ribbons or strips of stem to extract the bast fibres. This is usually achieved by a manual operation, hammer mill, inclined plane/fluted rollers or willower. Specifically for flax, the process is often referred to as "scutching"

Hackling is the combing of long (line) flax fibres in order to remove short fibres, to parallelise the remaining fibres and also to remove any extraneous matter (shive).

Carding is a process to disentangle and align fibres by working them between two closely spaced, relatively moving surfaces clothed with pointed wire, pins, spikes or saw teeth. The product is known as sliver.

Gilling (or pin drafting) is combing of the sliver to decrease the mass per unit length.

Spinning is the drafting and twisting of natural (or man-made) fibres to produce yarn (also known as filaments). In the bast-fibre industry, the terms 'wet spinning' and 'dry spinning' refer to the spinning of fibres in the wet state or in the dry state respectively.

A similar growth and processing route to that described above is followed for the production of the other bast fibres. Flax is probably the most labour and agrochemical intensive of the bast fibres [16], The other natural fibres normally have reduced agro-chemical inputs and will thus impose a lower environmental burden.

Subsequent treatment of natural fibre textiles [16] may include:

Acetylation: the process of introducing an acetyl radical into an organic molecule. The term is used to describe the process of combining cellulose with acetic acid (or precursors for the acid). The reduced number of hydroxyl groups after acetylation confers a more hydrophobic character to the fibres.

Bleaching: any procedure (other than scouring alone) of improving the whiteness of textile material by decolorizing it from the grey state, with or without the removal of natural colouring and/or extraneous substances. The removal of colour from dyed or printed textiles is usually called "stripping".

Grafting: the incorporation of monomers (e.g. cyanoethylation: reaction with acrylonitrile) or oligomers (short chain polymers) at the fibre surface by chemical reaction.

Mercerisation: the treatment of cellulosic textiles in yarn or fabric form with a concentrated solution of caustic alkali [soda], whereby the fibres are swollen, the strength and dye affinity of the materials are increased, and their handle is modified. The process takes its name from its discoverer, John Mercer (1844).

Scouring (solvent treatment): the treatment of textile materials in aqueous or other solvents in order to remove natural fats, waxes, proteins and other constituents, as well as dirt, oil, and other impurities.

Kalia [39] has recently reviewed pretreatments for natural fibres intended to improve their effectiveness when used as the reinforcement in polymer composites.

\section{Characterisation of the fibres}

Chemical and physical structure

The principal components of the fibre cell walls are cellulose, hemicelluloses and lignin with pectin normally considered to be the main binder (Table 1).

\section{Table 1: Proportions of the principal components of raw hemp bast - data from [40].}

Cellulose is the most important structural component of nearly all green plant cell walls, especially in many natural fibres (flax, jute, hemp, cotton, etc). The cellulose polymer is composed entirely of carbon, hydrogen and oxygen (the molecular formula can be written as if it consisted of only carbon and water, hence the name carbohydrate). Cellulose is a polysaccharide $\left(\mathrm{C}_{6} \mathrm{H}_{10} \mathrm{O}_{5}\right)_{n}$ which can be degraded to give only glucose $\left(\mathrm{C}_{6} \mathrm{H}_{12} \mathrm{O}_{6}\right)$. The smallest repeat unit is cellobiose $\left(\mathrm{C}_{6} \mathrm{H}_{11} \mathrm{O}_{5}\right)_{2} \mathrm{O}$ formed by the condensation of two glucose units and hence is also known as anhydroglucose (glucose minus water). Cellulose is a strong, linear (crystalline) molecule with no branching. Cellulose has good resistance to hydrolysis although all chemical and solution treatments will degrade it to some extent. Resources on cellulose can be found at references [41-44].

Hemicelluloses are lower molecular weight polysaccharides, often copolymers of glucose, glucuronic acid, mannose, arabinose and xylose, which may form random, amorphous branched or nonlinear structures with little strength. Hemicellulose is easily hydrolyzed by dilute acids or bases, but nature also provides an arsenal of hemicellulase enzymes for its hydrolysis. These enzymes are commercially important because they open up structure bound cellulose materials [45-47].

Lignin [47] is formed by non-reversible removal of water from sugars (primarily xylose) to create aromatic structures. Lignification progresses as the plant matures conferring mechanical stability to the plant. As lignin becomes more rigid, it is localised away from the lumen surface and porous wall regions to maintain wall strength and permeability and help with the transport of water [48]. Lignin resists attack by most microorganisms as the aromatic rings are resistant to anaerobic processes while aerobic breakdown of lignin is slow. 
Vincent [49] states that the elementary fibril of cellulose is about $3.5 \mathrm{~nm}$ diameter and contains about 40 molecules. The cellulose elementary fibrils can be arranged into larger fibrils of 20-25 nm diameter. They are formed by neighbouring cellulose chains forming hydrogen bonds leading to partially crystalline regions (micelles). These form a strong structural framework in the cell walls. Cellulose found in plants as microfibrils may be 2-20 nm diameter and $100 \mathrm{~nm}$ $40 \mu \mathrm{m}$ long) [42].

\section{Mechanical properties}

Cellulose has been estimated to have a modulus of $140 \mathrm{GPa}$ when using X-ray diffraction to determine the strain [49]. A slightly higher figure has been obtained by calculation from the chemical structure of the crystal with consideration of the straightening of the covalent bonds and stretching of the interchain hydrogen bonds. If hydrogen bonding is not included in the calculation, then the modulus drops by a factor of $\sim 8$. Experimentally measured moduli will inevitably be lower than theoretical values (due to $<100 \%$ crystallinity and off-axis fibre orientation). Nevertheless, Vincent has reported values of $100 \mathrm{GPa}$ for dry flax and $\sim 80 \mathrm{GPa}$ for wet flax. As water penetrates the amorphous regions of cellulose, the stiffness can drop by a factor of 2-4 as the contribution of the hydrogen bonding is progressively removed. Table 2 presents some mechanical property data for bast fibres.

Table 2: Typical properties of some bast fibres, with comparative values for E-glass

Table 3: The angle between the cellulose chains and cell length [57]

(extracted from RD Preston, The Physical Biology of Plant Cell Walls, 1974, page 293)

Table 3 presents the winding angle of the cellulose molecule relative to the principal axis for some natural fibres. Figure 3 presents reported elastic moduli against winding angle for several plant fibres. The Krenchel [62] equation permits calculation of the effectiveness of a mis-aligned fibre reinforcement, as a fibre orientation distribution factor, using the proportions of fibre at each angle and the fourth power of the cosine of the angle between the fibre and the reference direction. The $\cos ^{4} \theta$ line is forced through the data point for cotton (seed fibre) in the Figure to indicate the applicability of this model to the molecular winding angle in the fibre for this limited data set regardless of the source of the fibre.

Figure 3: The dependence of the elastic modulus of plant fibres on the angle between the cellulose molecules and the fibre principal axis for bast fibres (solid markers), leaf fibres (sisal) and seed fibres (cotton): data from Chand et al [1], Vincent [49], Preston [59] and Preston and Middlebrook [60] and Virk [61] with the Krenchel [62] $\cos ^{4} \theta$ dependence on the orientation forced though the cotton data.

\section{Fibre Quality}

Unlike synthetic reinforcement fibres, the natural fibres are perceived to have significantly greater variability in their mechanical properties as a consequence of the conditions experienced in the field and the potential damage arising from the above processes, especially over-retting. The harsh conditions during harvest may introduce damage and it is common to see mechanical damage in extracted fibres.

The textile industry, and many researchers in the composite field, assume that fibres are of a regular circular crosssection and use microscopy transverse to the principal axis to determine a characteristic dimension (incorrectly referred to as the diameter). Figure 4 is a confocal scanning laser microscope image of a cluster of elementary jute fibres: these fibres (which are typical of bast fibres) are clearly not round. Further the dimensions of each cell in the fibre will change along the length.

\section{Figure 4: Confocal Scanning Laser Microscope (CSLM) image of a cluster of elementary jute fibres,} (image acquired by Amandeep Singh Virk).

Figure 4 also shows that each elementary fibre normally has a central hollow channel (the lumen). This feature will introduce additional porosity into the composite (voids within synthetic fibres are comparatively rare) and will reduce the cross-section of fibre material available to carry load.

The elastic modulus (and ultimate tensile strength) of the individual filaments can be determined by ASTM D3379-75 (now withdrawn), Grafil Test Method 101.13 [63] for $50 \mathrm{~mm}$ fibres or the French norm NFT25-704. The corresponding values for fibre tows can be determined by Grafil Test Method 103.22 [63]. However, these methods tend to assume that the fibre has a regular cross-section with no lumen.

Virk et al [61] undertook one hundred tensile tests at each of five distinct fibre lengths $(6,10,20,30$ and $50 \mathrm{~mm})$ on a single batch of jute fibres. The Young's modulus was found to be $30 \mathrm{GPa}$ while the ultimate strength and fracture strain fell from 558 to $336 \mathrm{MPa}$ and from 1.79 to $1.11 \%$ respectively as the length increased from 6 to $50 \mathrm{~mm}$. 
Virk et al [64] studied the mechanical characteristics of 785 jute technical fibres in batches of at least 50 at each of 10 lengths ranging from $6 \mathrm{~mm}$ to $300 \mathrm{~mm}$. Fracture strain was found to be a more consistent parameter than strength (fracture stress). Coefficients of variation (COV) for each batch were in the range 0.19-0.35 for fracture strain and in the range 0.33-0.46 for strength, with the mean COV for strain reduced by at least $25 \%$ relative to that for strength. Note that failure strain is independent of the fibre cross-sectional area while the strength relies on an accurate determination of the cross-sectional area. The variability in the strength of natural fibres arises from the methods used for determination of cross-sectional area especially where an effective diameter is derived from linear measurements.

\section{Research opportunities \\ Stochastic variation}

Kittl and Diáz [65] have reviewed the state of the art in probabilistic strength of materials and Weibull fracture statistics. In [66], van der Zwaag reviewed the concept of filament strength and the Weibull modulus. However, these papers are now twenty years old and it would timely to see a new review specific to the application of statistical techniques to natural fibres and their composites.

\section{Fibre degradation}

The thermal decomposition temperature of cellulose fibres is generally regarded as being around $200^{\circ} \mathrm{C}$, although this response is obviously a function of time at temperature, and will limit the choice of the polymer matrix system for composites. Initial decomposition of cellulose fibres occurs primarily in the amorphous regions. Table 4 summarises the data reported for thermal degradation of flax fibres. Ray et al [67] reported that the decomposition temperature for crystalline $\alpha$-cellulose in untreated jute fibres was $362.2{ }^{\circ} \mathrm{C}$, but fell to $348{ }^{\circ} \mathrm{C}$ after mercerisation. Kim et al [68] studied three forms of $\alpha$-cellulose and found that the decomposition began at $285^{\circ} \mathrm{C}$ (Funacel microcrystalline cellulose), $305^{\circ} \mathrm{C}$ (cotton) and $325^{\circ} \mathrm{C}$ (Holocynthia) with rapid weight loss at $315-360{ }^{\circ} \mathrm{C}, 340-380{ }^{\circ} \mathrm{C}$ and $370-410{ }^{\circ} \mathrm{C}$ respectively. The activation energy was in the range $159-166 \mathrm{~kJ} / \mathrm{mol}$ regardless of the type.

\section{Table 4: Thermal degradation of flax fibres}

The cellulose molecule is hydrophilic and hence the fibre properties are sensitive to the relative humidity of the environment in which they are processed and/or used. This topic deserves a review paper in its own right.

\section{The fibre-matrix interface}

The realisation of the full mechanical performance of the reinforcement is critically dependent on the effective load transfer by shear over the "half critical length" at each fibre end, which in turn is a function of the chemical and physical bonds between the fibre and the matrix. The main approaches to enhancement of the interaction between the fibre and the matrix are surface modification of the fibre (grafting or other chemical/physical treatments), application of coupling agents to the fibre surface and/or the use of compatibilisers in the matrix. George et al [69] have critically reviewed the physical and chemical treatments that may improve the fibre-matrix adhesion. They conclude that good compatibility between cellulose fibres and non-polar matrices is achieved using polymers that favour entanglement and interdiffusion with the matrix. A new review to update that by George et al [69] would be timely.

Xie et al [70] have reviewed the use of silane coupling agents in natural fibre/polymer composites. They concluded that proper treatment of fibres with silanes can increase the interfacial adhesion and improve the mechanical and outdoor performance of the resulting composites. However, the Si-O-C bonds in natural fibre composites are less stable under hydrolysis than the Si-O-Si bonds in glass fibre composites [71].

\section{Reinforcement Forms for Composites}

The effective utilisation of the properties of a fibre as a reinforcement is a function of the fibre length and the fibre orientation with respect to the stress (see Prediction of mechanical properties in Part 2 of this review). These two fibre parameters are generally present with a statistical variation and hence are measured as the fibre length distribution factor $\left(\eta_{l}\right)$ and the fibre orientation distribution factor $\left(\eta_{o}\right)$. Both parameters range between 0 (short fibres or alignment transverse to the stress respectively) and 1 (continuous fibres or aligned with the stress respectively). Typical reinforcement forms are unidirectional $\left(\eta_{l}=1\right.$ and $\eta_{o}=1$ when continuous fibres are aligned with the stress), woven fabrics $\left(\eta_{l}=1\right.$ and $\eta_{o}=0.5$ when one set of fibres is aligned with the stress) and random chopped strand mats $\left(\eta_{l}<1\right.$ and $\left.\eta_{o}=3 / 8\right)$.

Increasing alignment of the fibres enables more fibre to be incorporated into the composite. For practical purposes, the limiting fibre volume fractions are around 75\% (unidirectional), 65\% (woven) or 30\% (random orientation). A major constraint on the effective use of natural fibre reinforcements is that the materials supply chain has not had a costeffective environmentally-friendly methodology for the production of woven or otherwise aligned fabrics. 


\section{SUMMARY}

This review paper has considered the growth, harvesting and fibre separation techniques suitable to yield bast fibre of appropriate quality for use as the reinforcement of polymer-matrix composites. The text then addressed the characterisation of the fibre. Bast fibres have weight specific properties which may be superior to the corresponding properties of glass fibre reinforcements and are perceived as being less problematic in the context of environmental burden. However, there are a number of factors which could constrain the commercial adoption of these fibres as reinforcements:

- Plants grown in temperate zones are normally harvested in late summer or autumn which has significant implications for the supply chain.

- Fibre properties are dependent on the weather during the growing season

- Fibres may suffer mechanical damage during mechanised harvesting.

- Fibres are extracted from the plant stem by retting, but it is difficult to determine the correct point at which to terminate the process and over-retting can reduce the fibre properties.

- The proportion of fibre extracted from a stem may be $<10 \%$ by weight and the co-products are of low commercial value (short fibre for paper or animal bedding, or compressed dust as a fuel).

- Fibre as sliver could replace random mat reinforcements, but it is necessary to spin the fibres to produce continuous yarns for the production of reinforcement fabrics.

- Fibres have an irregular cross section with a central void (lumen) which makes the determination of their mechanical properties more complex than for solid circular glass fibres.

- Cellulose is a hydrophilic molecule, so the fibres have properties which are dependent on the water content.

- Fibres degrade over time at temperatures of $\sim 200^{\circ} \mathrm{C}$ or higher, so the choice of matrix system for the composite is limited.

\section{ACKNOWLEDGEMENTS}

The authors would like to thank (a) our former colleague, Hom Nath Dhakal (now University of Portsmouth), for his comments on draft versions of this paper, (b) Richard Cullen (University of Plymouth) for permission to use his data in Figure 1, (c) Joachim Gingele (University of Plymouth) for translations from German, (d) Stephen Grove (University of Plymouth) for help in reverse engineering data and (e) the referees who considered an earlier version of this paper and offered some very useful advice. ASV is grateful to the University of Plymouth Faculty of Science and Technology for a scholarship to pursue his $\mathrm{PhD}$.

\section{REFERENCES}

1 N Chand, RK Tiwary and PK Rohatgi, Resource structure properties of natural cellulosic fibers - an annotatedbibliography, Journal of Materials Science, February 1988, 23(2), 381-387

2 H Lilholt and JM Lawther, Chapter 10: Natural Organic Fibers, In T-W Chou (editor): "Comprehensive Composite Materials Encyclopadia, volume 1: Fiber Reinforcements and General Theory of Composites ", Elsevier Science, Oxford, July 2000, pp 303-325. ISBN 0-08-043719-2.

$3 \quad$ RR Franck, Bast and Other Plant Fibres, CRC Press, Boca Raton FL, April 2005. ISBN 0-8493-2597-8.

4 AJ Bolton, Natural fibers for plastic reinforcement, Materials Technology, 1994, 9(1-2), 12-20.

5 AK Mohanty and M Misra, Studies on jute composites: a literature review, Polymer - Plastics Technology and Engineering, 1995, 34(5), 729-792.

6 D Nabi Saheb and JP Jog, Natural fibre polymer composites: a review, Advances in Polymer Technology, 1999, $18(4), 315-363$.

7 AK Bledzki, VE Sperber and O Faruk, Natural and wood fibre reinforcements in polymers, Report 152, RAPRA Technology, 2002. ISBN 1-85957-359-2. RAPRA Review Reports, 13(8), RAPRA Technology, Shropshire, 2002, ISSN 0889-3144.

8 AN Netravali and Shitij Chabba, Composites get greener, Materials Today, April 2003, 6(4), 22-29.

9 C Baillie, Green Composites: polymer composites and the environment, Woodhead Publishing Limited, Cambridge, 2004. ISBN 1-85573-739-6.

10 AK Mohanty, M Misra and LT Drzal, Natural Fibers, Biopolymers, and Biocomposites, CRC Press/Taylor \& Francis Group, Boca Raton FL, 2005. ISBN 0-8493-1741-X.

11 K Pickering, Properties and performance of natural-fibre composites, Woodhead Publishing, Cambridge, 2008. ISBN-13: 9781845692674.

12 T Scheibel, Spider silks: recombinant synthesis, assembly, spinning, and engineering of synthetic proteins, Microbial Cell Factories 2004. http://www.microbialcellfactories.com/content/3/1/14, 3:14, accessed 19 January 2009 at 16:55.

13 AS Blicblau, RSP Coutts and A Sims, Novel composites utilizing raw wool and polyester resin, Journal of Materials Science Letters, 1 September 1997, 16(17), 1417-1419.

14 RMN Arib, SM Sapuan, MAMM Hamdan, MT Paridah and HMDK Zaman, A literature review of pineapple fibre reinforced polymer composites, Polymers and Polymer Composites, 2004, 12(4), 341-348. 
Y Li, Y-W Mai and L Ye, Sisal fibre and its composites: a review of recent developments, Composites Science and Technology, 2000, 60(11), 2037-2055.

16 CA Farnfield and PJ Alvey (editors), Textile Terms and Definitions - seventh edition, The Textile Institute, Manchester, 1975. ISBN 0-900739-17-7 and MJ Denton and PN Daniels (editors), Textile Terms and Definitions - eleventh edition, The Textile Institute, Manchester, 2002. ISBN 1-87037-244-1.

17 JE McIntyre, The Chemistry of Fibres (Studies in Chemistry 6), Edward Arnold, 1971. ISBN 0-7131-2328-1.

18 E Kvavadze, O Bar-Yosef, A Belfer-Cohen, E Boaretto, N Jakeli, Z Matskevich, T Meshveliani, $\underline{30,000-Y e a r-}$ Old Wild Flax Fibers, Science, 11 September 2009, 325(5946), 1359

19 JA Turner, Linseed Law: A handbook for growers and advisers, BASF (UK) Limited, Hadleigh - Suffolk, June 1987. ISBN 0-9502752-2-0.

20 HS Shekhar Sharma and CF van Sumere, The biology and processing of flax, M Publications, Belfast, c1992. ISBN 0-9519963-0-4.

21 A Lewington, Plants for People, Eden Project Books/Transworld Publisher, London, 2003. ISBN 1-903-919088 .

22 AD Muir and ND Westcott, Flax: The genus Linum, CRC Press, Boca Raton FL, 2003. ISBN 0-4153-0807-0.

23 Flax Council of Canada, http://www.flaxcouncil.ca/, accessed 19 January 2009 at 16:56.

24 Auto body made of plastics resists denting under hard blows, Popular Mechanics, December 1941, 76(6), xxx

25 AK Bledzki and J Gassan, Composites reinforced with cellulose based fibres, Progress in Polymer Science, 1999, 24(2), 221-274.

$26 \mathrm{~S}$ ben Brahim and $\mathrm{R}$ ben Cheikh, Influence of fibre orientation and volume fraction on the tensile properties of unidirectional alfa-polyester composite, Composites Science and Technology, January 2007, 67(1), 140-147.

27 P de Leo, A Miceli, C Antonaci and G Vigna, Characterisation and enzymatic hydrolysis of nettle (Urtica dioica L) deproteinated biomass, Journal of the Science of Food and Agriculture, 1993, 63(4), 391-395.

28 J Dreyer, G Dreyling and F Feldmann, Wiederinkulturahme der Fasernessel Urtica dioica $\mathrm{L}$ als nachwachsender Rohstoff zur Faser- und Zellstoffproduktion: qualitative und quantitative Differenzierung von ehemals genutzten Klonen, Angewandte Botanik - Journal of Applied Botany, May 1996, 70(1-2), 28-39.

29 GC Davies and DM Bruce, Effect of environmental relative humidity and damage on the tensile properties of flax and nettle fibres, Textile Research Journal, September 1998, 68(9), 623-629.

30 SC Singh and R Shrestha, Extraction and chemical analysis of Himalayan nettle fibre, Research and Industry, December 1987, 32(4), 259-262.

31 A Hartl and CR Vogl, Dry matter and fiber yields, and the fiber characteristics of five nettle clones (Urtica dioica L.) organically grown in Austria for potential textile use, American Journal of Alternative Agriculture, 2002, 17(4), 195-200. ISSN 0889-1893.

32 About Kenaf, http://www.chinaconsultinginc.com/modules.php?name=Sections\&op=viewarticle\&artid=5, accessed 19 January 2009 at 16:59.

33 Ontario Ministry of Agriculture, Food and Rural Affairs (OMAFRA) staff, Agronomy Guide For Field Crops chapter 9 section 2: Flax, OMAFRA Publication 811, 01 March 2002, accessed 19 January 2009 at 17:00.

34 Guidelines for growing flax, University of Wales Bangor Henfaes Research Centre, 29 September 2004, accessed 19 January 2009 at 17:00.

35 DR Kashyap, PK Vohra, S Chopra and R Tewari, Applications of pectinases in the commercial sector: a review, Bioresource Technology, May 2001, 77(3), 215-227.

36 HSS Sharma, PC Mercer and AE Brown, Review of recent research on the retting of flax in Northern Ireland, International Biodeterioration, 1989, 25(5), 327-342.

37 Webster's Revised Unabridged Dictionary (1913) [web, 1913]:

http://www.beetfoundation.com/words/d/decortication.html, accessed 19 January 2009 at 17:02.

38 The Concise English Dictionary, Oxford University Press, Oxford, 1977.

39 S Kalia, BS Kaith and I Kaur, Pretreatments of natural fibers and their application as reinforcing material in polymer composites - a review, Polymer Engineering and Science, July 2009, 49(7), 1253 - 1272.

40 SK Batra, Other long vegetable fibres, in M Lewin and EM Pearce (editors): Handbook of Fibre Chemistry, Marcel Dekker,New York, 1998, 530-xxx.

41 T Heinze and K Fischer (editors), Cellulose And Cellulose Derivatives, John Wiley \& Sons Inc, 2005. ISBN13: 978-3-52731326-6.

42 M Chaplin, Cellulose, http://www.lsbu.ac.uk/water/hycel.html, 01 July 2008, accessed 19 January 2009 at 17:04.

43 P v. Sengbusch, Cellulose, http://www.biologie.uni-hamburg.de/b-online/e26/26a.htm, 31 July 2003, accessed 19 January 2009 at 17:05.

44 Cellulose, http://www.fibersource.com/f-tutor/cellulose.htm, accessed 19 January 2009 at 17:11..

45 H Bungay, Starch and Cellulose, http://www.rpi.edu/dept/chem-eng/BiotechEnviron/FUNDAMNT/cellulos.htm, 12 December 1997, accessed 19 January 2009 at 17:18.

46 H Bungay, Hemicellulose, http://www.rpi.edu/dept/chem-eng/Biotech-Environ/FUNDAMNT/hemicel.htm, July 1996, accessed 19 January 2009 at 17:16.

47 H Bungay, Lignin, http://www.rpi.edu/dept/chem-eng/Biotech-Environ/FUNDAMNT/lignin.htm, July 1996, accessed 19 January 2009 at 17:17. 
JS. Sperry, Evolution of water transport and xylem structure, International Journal of Plant Sciences, 2003, 164(S3), S115-S127.

49 JFV Vincent, Structural Biomaterials, Macmillan, London, 1982. ISBN 0-333-26126-7.

50 NL Hancox, Fibre Composite Hybrid Materials, Elsevier Applied Science, Barking, 1981. ISBN 0-85334-928-2.

51 C Baley, Analysis of the flax fibres tensile behaviour and analysis of the tensile stiffness increase, Composites Part A: Applied Science and Manufacturing, July 2002, 33(7), 939-948.

52 SH Aziz and MP Ansell, The effect of alkalization and fibre alignment on the mechanical and thermal properties of kenaf and hemp bast fibre composites: Part 1 - polyester resin matrix, Composites Science and Technology, July 2004, 64(9), 1219-1230.

53 S Ochi, Mechanical properties of kenaf fibers and kenaf/PLA composites, Mechanics of Materials, April-May 2008, 40(4-5), 446-452.

54 E Bodros and C Baley, Study of the tensile properties of stinging nettle fibres (Urtica dioica), Materials Letters, 15 May 2008, 62(14), 2143-2145.

55 A Beukers, In: A Beukers and E van Hinte (editors), Lightness: the inevitable renaissance of minimum energy structures, 010 Publishers, Rotterdam, 1999. page 72. ISBN 9789064505607.

56 P Wambua, J Ivens and I Verpoest, Natural fibres: can they replace glass in fibre reinforced plastics?, Composites Science and Technology, 2003, 63(9), 1259-1264.

57 RD Preston, The Physical Biology of Plant Cell Walls, Chapman \& Hall, London, 1974. ISBN 0-412-11600-6.

58 BC Kundu and RD Preston, The fine structure of phloem fibres I: Untreated and swollen hemp, Proceedings of the Royal Society, 1940, B128, 214-231.

59 RD Preston, The fine structure of phloem fibres II: untreated and swollen jute, Proceedings of the Royal Society, 1941, B130, 103-112.

60 RD Preston and M Middlebrook, The fine structure of sisal fibres, Journal of the Textile Institute, 1949, 40(.), T715-T722 + Plates I/II.

61 AS Virk, W Hall and J Summerscales, The tensile properties of jute fibres, Materials Science and Technology, October 2009, 25(10), 1289-1295..

62 H Krenchel, Fibre Reinforcement, Akademisk Forlag, Copenhagen, 1964.

63 Grafil Test Methods (reference 000.05), Courtaulds Limited, Coventry, March 1980.

64 AS Virk, W Hall and J Summerscales, Strain as the key design criterion for failure of natural fibre composites, Composites Science and Technology, June 2010, 70(6), 995-999.

65 P Kittl and G Diáz, Weibull's fracture statistics, or probabilistic strength of materials: state of the art, Res Mechanica, 1988, 24(2), 99-207.

66 S van der Zwaag, The concept of filament strength and the Weibull modulus, Journal of Testing and Evaluation, September 1989, 17(5), 292-298.

67 D Ray, BK Sarkar, RK Basak and AK Rana, Study of the thermal behavior of alkali-treated jute fibers, Journal of Applied Polymer Science, 19 September 2002, 85(12), 2594-2599.

68 U-J Kim, SH Eom and M Wada, Thermal decomposition of native cellulose: influence on crystallite size, Polymer Degradation and Stability, May 2010, 95(5), 778-781.

69 J George, MS Sreekala and S Thomas, A review of interface modification and characterisation of natural fibre reinforced plastic composites, Polymer Engineering and Science, September 2001, 41(9), 1471-1485.

70 Y Xie, CAS Hill, Z Xiao, H Militz and C Mai, Silane coupling agents used for natural fiber/polymer composites: a review, Composites Part A: Applied Science and Manufacturing, July 2010, 41(7), 806-819.

71 EP Plueddemann, Silane Coupling Agents - second edition, Plenum Press, New York, 1991. ISBN 978-0-30643473-0.

72 J Gassan and AK Bledzki, Thermal degradation of flax and jute fibers, Journal of Applied Polymer Science, 2001, 82(6), 1417-1422.

73 B. Wielage, Th. Lampke, G. Marx, K. Nestler and D. Starke, Thermogravimetric and differential scanning calorimetric analysis of natural fibres and polypropylene, Thermochimica Acta, 11 October 1999, 337(1-2), 169177.

74 R. Kohler and M. Wedler, Nichttextile Anwendungen von Flachs. In Proc Techtextil-Symposium 6 (1994). Internationale Tagung: Frankfurt/Main, Germany, 1994, Paper 331, pages 1-8.

75 K-P Mieck, A Nechwatal and C Knobelsdorf, Anwendungsmöglichkeiten von Naturfaserstoffen bei Verbundmaterial, Melliand Textilberichte, 1994, 11, 892-898. 
Final draft manuscript of a paper published in Composites Part A

Applied Science and Manufacturing 41, (10) 1329-1335 , DOI: 10.1016/i.compositesa.2010.06.001

Table 1: Proportions of the principal components of raw hemp bast - data from [40] (SK Batra, 1998).

\begin{tabular}{c|cc}
\hline Component & Minimum proportion & Maximum proportion \\
\hline Cellulose & $67.0 \%$ & $78.3 \%$ \\
Hemicellulose & $5.5 \%$ & $16.1 \%$ \\
Lignin & $2.9 \%$ & $3.3 \%$ \\
\hline Pectin & $0.8 \%$ & $2.5 \%$ \\
\hline
\end{tabular}

Table 2: Typical properties of some bast fibres, with comparative values for E-glass

\begin{tabular}{|c|c|c|c|c|c|c|}
\hline \multirow[t]{2}{*}{ Properties } & \multicolumn{6}{|l|}{ Fibre } \\
\hline & E-glass [50] & Flax[51] & Hemp [50] & Jute[50] & Kenaf & Nettle [54] \\
\hline Density $\mathbf{k g} / \mathbf{m}^{3}(\rho)$ & 2550 & 1530 & 1520 & 1520 & $1193[52]$ & - \\
\hline E-modulus (GPa) & 71 & $58 \pm 15$ & 70 & 60 & $14-38[53]$ & $87 \pm 28$ \\
\hline Tensile strength (MPa) & 3400 & $1339 \pm 486$ & 920 & 860 & $240-600[53]$ & $1594 \pm 640$ \\
\hline Specific modulus (E/1000p) & 28 & 38 & 46 & 39 & $12-32$ & - \\
\hline Elongation at failure (\%) & 3.4 & $3.27 \pm 0.4$ & 1.7 & 2 & - & $2.11 \pm 0.81$ \\
\hline Moisture absorption (\%) [55 via 56] & - & 7 & 8 & 12 & - & - \\
\hline
\end{tabular}

Table 3: The angle between the cellulose chains and cell length [57]

(extracted from RD Preston, The Physical Biology of Plant Cell Walls, 1974, page 293)

$$
\text { Plant/technique } \quad \theta^{\circ} \text { (range) } \theta^{\circ} \text { (average) } \text { Source }
$$

\section{Cannabis sativa (hemp)}

optical microscopy: major extinction position

$0.0-5.0$

striations

$0.0-6.0$

$2.0 \pm 0.3$

[58] (Kundu and Preston, 1940)

Corchorus capsularis (jute)

optical microscopy: major extinction position

$0.0-23.0$

7.9

[59] (Preston, 1941)

Agave sisalana (sisal leaf fibre)

optical microscopy: major extinction position

X-rays

\section{0-32.3 $20.4 \pm 7.2 \quad[60]$ (Preston and Middlebrook, 1949)}

18 [60] (Preston and Middlebrook, 1949)

\begin{tabular}{|c|c|c|c|}
\hline \multicolumn{4}{|c}{ Table 4: Thermal degradation of flax fibres } \\
\hline Temperature $\left({ }^{\circ} \mathbf{C}\right)$ & Time (minutes) & Decrease in strength $(\%)$ & Reference \\
\hline 170 & 120 & 0 & 72 Gassan \\
\hline 180 & 60 & 24 & 73 Wielage \\
\hline 200 & 30 & 36 & 73 Wielage \\
\hline 200 & 60 & 47 & 74 Kohler \\
\hline 210 & 120 & 50 & 72 Gassan \\
\hline 220 & 60 & 62 & 73 Wielage \\
\hline 250 & 4 & 20 & 75 Mieck \\
\hline 250 & 12 & 57 & 75 Mieck \\
\hline
\end{tabular}



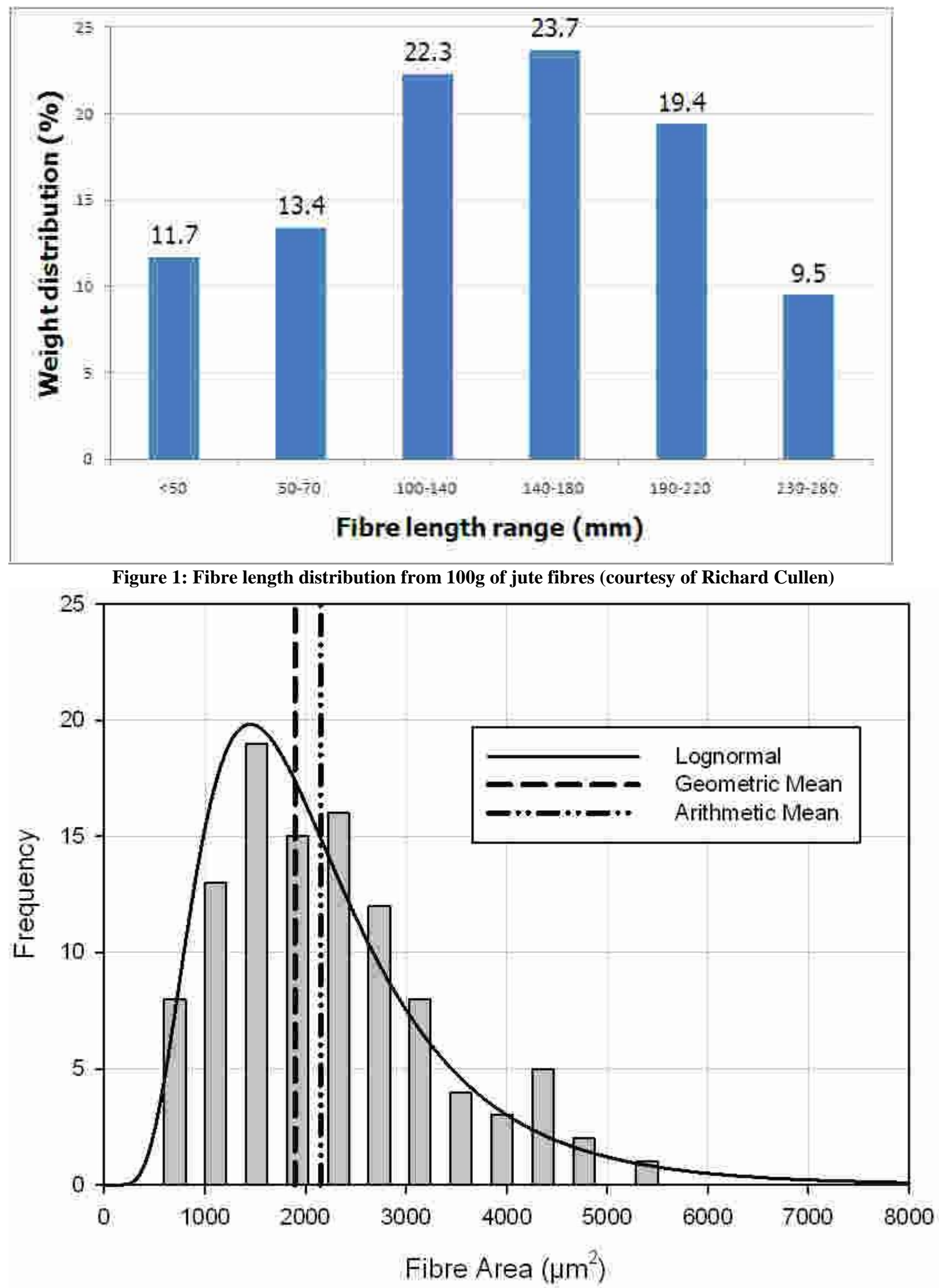

Figure 2:Distribution of fibre cross-sectional areas for jute fibres (Virk data) 
Final draft manuscript of a paper published in Composites Part A

Applied Science and Manufacturing 41, (10) 1329-1335 , DOI: 10.1016/i.compositesa.2010.06.001

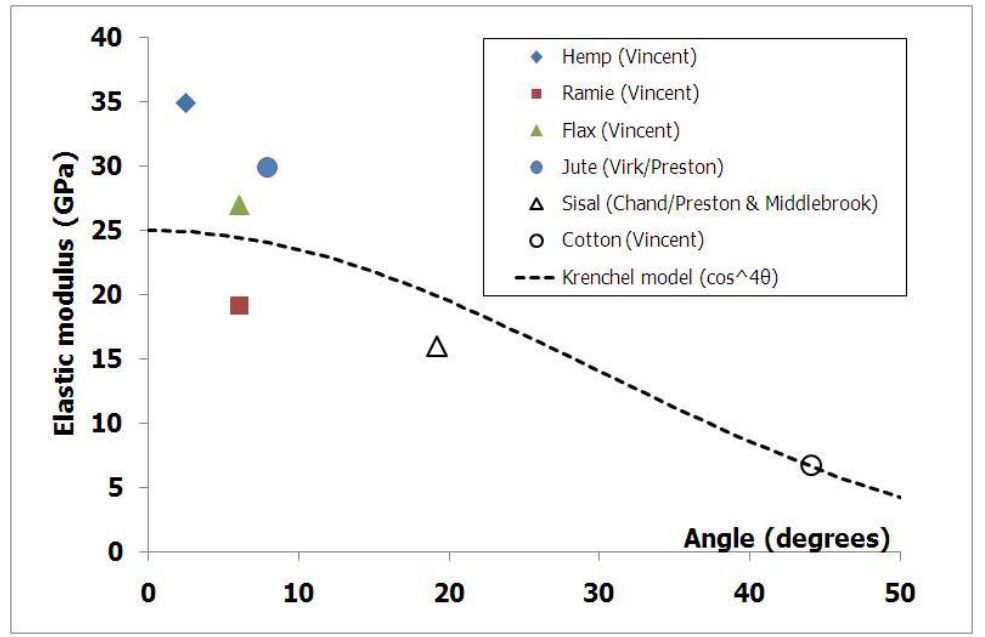

Figure 3: The dependence of the elastic modulus of plant fibres on the angle between the cellulose molecules and the fibre principal axis for bast fibres (solid markers), leaf fibres (sisal) and seed fibres (cotton) combining data from Chand et al [1], Vincent [49], Preston [59] and Preston and Middlebrook [60] and Virk [61] with the Krenchel [62] model for $\cos ^{4} \theta$ dependence on the fibre orientation forced though the cotton data.

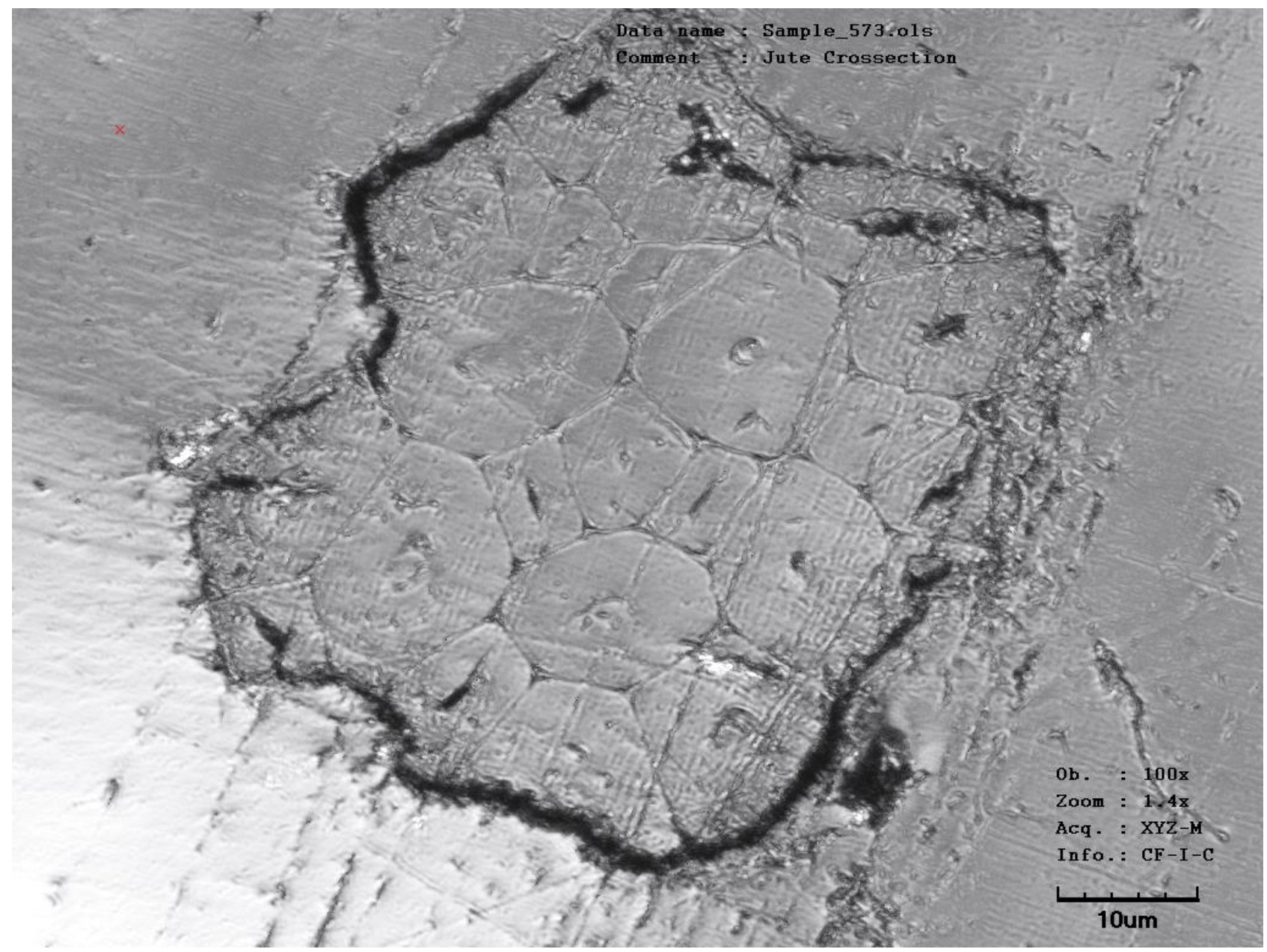

Figure 4: Confocal Scanning Laser Microscope (CSLM) image of a cluster of elementary jute fibres, (image acquired by Amandeep Singh Virk). 